\title{
THE
}

\section{Plasma Clearance of Lovastatin Versus Chinese Red Yeast Rice in Healthy Volunteers}

\author{
Zhaoping Li \\ Navindra P. Seeram \\ University of Rhode Island, nseeram@uri.edu \\ Rupo Lee \\ Gail Thames \\ Chayo Minutti
}

See next page for additional authors

Follow this and additional works at: https://digitalcommons.uri.edu/bps_facpubs

Terms of Use

All rights reserved under copyright.

\section{Citation/Publisher Attribution}

Li, Z., Seeram, N. P., Lee, R., Thames, G., Minutti, C., Wang, H.-J., \& Heber, D. (2005). Plasma Clearance of Lovastatin Versus Chinese Red Yeast Rice in Healthy Volunteers. The Journal of Alternative and Complementary Medicine, 11(6), 1031-1038. doi; 10.1089/acm.2005.11.1031

Available at: http://dx.doi.org/10.1089/acm.2005.11.1031

This Article is brought to you for free and open access by the Biomedical and Pharmaceutical Sciences at DigitalCommons@URI. It has been accepted for inclusion in Biomedical and Pharmaceutical Sciences Faculty Publications by an authorized administrator of DigitalCommons@URI. For more information, please contact digitalcommons-group@uri.edu. 


\section{Authors}

Zhaoping Li, Navindra P. Seeram, Rupo Lee, Gail Thames, Chayo Minutti, He-Jing Wang, and David Heber 


\title{
Plasma Clearance of Lovastatin Versus Chinese Red Yeast Rice in Healthy Volunteers
}

\author{
ZHAOPING LI, Ph.D., M.D., NAVINDRA P. SEERAM, Ph.D., RUPO LEE, M.Sc., GAIL THAMES, B.A., \\ CHAYO MINUTTI, HE-JING WANG, M.P.H., M.D., and DAVID HEBER, Ph.D., M.D.
}

\begin{abstract}
Objectives: It is now accepted that inhibition of cholesterol biosynthesis is effective in the primary and secondary prevention of heart disease. However, the perceived side-effects on muscle and liver reduce the general acceptance of statin drug therapy as well as compliance over the long term, which is necessary for prevention efforts to be successful. Chinese red yeast rice (CRYR) is a supplement containing lovastatin (monacolin K), eight other monacolins, pigments, tannins, and other phytochemicals. The authors previously reported on a double-blind placebo-controlled trial of CRYR supplement in 80 individuals demonstrating a significant decrease in cholesterol levels from $250 \mathrm{mg} / \mathrm{dL}$ to $210 \mathrm{mg} / \mathrm{dL}$ over 8 weeks independent of diet. The current study compared the pharmacokinetics of CRYR with lovastatin at the same bioeffective dose for lowering cholesterol.

Methods: Eleven (11) healthy volunteers were randomized to a crossover study taking $2400 \mathrm{mg}$ CRYR or $20 \mathrm{mg}$ of lovastatin.

Results: The $\mathrm{C}_{\max }$ and area under the curve (AUC) of lovastatin were $22.42 \mathrm{ng} / \mathrm{mL}$, and 80.47 higher than CRYR ( $p=0.001$ and 0.002 , respectively). The $\mathrm{C}_{\max }$ for lovastatin hydroxy-acid was $36.63 \mathrm{ng} / \mathrm{mL}$ higher than the $\mathrm{C}_{\max }$ of CRYR hydroxy-acid $(p=0.001)$. The AUC of lovastatin hydroxy-acid was 258.5 greater than that of CRYR $(p=0.001)$.

Conclusions: The results suggested that the effect of CRYR on the cholesterol concentration might be caused by the additive and/or synergistic effects of monacolin K with other monacolins and substances in CRYR. It may lead to the ultimate development of a botanical supplement based on CRYR.
\end{abstract}

\section{INTRODUCTION}

$I^{t}$ is now accepted that inhibition of cholesterol biosynthesis is effective in the primary and secondary prevention of heart disease. Statin drugs, which are competitive inhibitors of HMG-CoA reductase, lower cholesterol levels and reduce the progression of atherosclerotic lesions while also stabilizing pre-existing atheromatous plaques. The perceived side-effects on muscle and liver reduce the general acceptance of statin drug therapy as well as compliance over the long term, which are necessary for prevention efforts to be successful. ${ }^{1}$ Surveys demonstrate that many Americans often turn to alternative herbal therapies for heart disease prevention rather than taking drugs, ${ }^{2,3}$ and view these as natural alternatives to drug therapy.

Chinese red yeast fermented on rice is a traditional food consumed throughout Asia. Its food value and medicinal value date back prior to its first recorded use in $800 \mathrm{AD} .{ }^{4,5} \mathrm{~A}$ dietary supplement of Chinese red yeast rice (CRYR) has been prepared that contains only a selected strain of Monascus purpureus Went yeast and white rice on which it was fermented. There are a number of constituents in the supplement including pigments, fatty acids, and polyketides (monacolins). ${ }^{6}$

The authors previously reported on a double-blinded placebo-controlled trial of this CRYR supplement in 80 individuals demonstrating a significant decrease in cholesterol

Center for Human Nutrition, David Geffen School of Medicine, University of California, Los Angeles, CA. 
Table 1. Constituents of Chinese Red Yeast Rice (LOT Number 20030401)

\begin{tabular}{lc}
\hline Rice starch & $73.4 \%$ \\
Fiber & $0.8 \%$ \\
Protein & $5.8 \%$ \\
Moisture & $\mathrm{ca} .6 \%$ \\
Pigments & $0.3 \%$ \\
Ash & $<3 \%$ \\
Phosphorus & $0.4 \%$ \\
Organic phosphorus & $0.02 \%$ \\
Fatty acids & $1.1 \%$ \\
Trace elements & \\
$\mathrm{Ca}$ & $0.443 \mathrm{mg} / \mathrm{g}$ \\
$\mathrm{Mg}$ & $1.094 \mathrm{mg} / \mathrm{g}$ \\
$\mathrm{Al}$ & $78 \mu \mathrm{g} / \mathrm{g}$ \\
$\mathrm{Fe}$ & $50 \mu \mathrm{g} / \mathrm{g}$ \\
$\mathrm{Mn}$ & $19 \mu \mathrm{g} / \mathrm{g}$ \\
$\mathrm{Cu}$ & $8.6 \mu \mathrm{g} / \mathrm{g}$ \\
$\mathrm{Ag}$ & $20.7 \mu \mathrm{g} / \mathrm{g}$ \\
$\mathrm{Pb}$ & $<1 \mathrm{ppm}$ \\
$\mathrm{Monacolins}$ & $0.4 \%$ \\
\hline
\end{tabular}

levels from $250 \mathrm{mg} / \mathrm{dL}$ to $210 \mathrm{mg} / \mathrm{dL}$ over 8 weeks independent of diet. ${ }^{7}$ The current study was designed to compare the pharmacokinetics of CRYR with lovastatin at the same bioeffective dose for lowering cholesterol to determine whether the body metabolizes complex mixtures of natural substances found in CRYR differently than lovastatin.

\section{METHODS}

\section{Subjects}

The study protocol was approved by the Ethics Committee of the University of California, Los Angeles and conducted at the General Clinical Research Unit (GCRC) of University of California, Los Angeles. Eleven (11) volunteers ages 25 to 45 year were recruited for the study. Written consent was obtained. All participants were in good health according to medical history, physical examination, electrocardiogram, and clinical laboratory measurements (serum chemistry, liver function tests, and hematology). Subjects were excluded if they were smokers, tobacco users, or taking any medication including over-the-counter medications within 14 days prior to the study.

\section{Study design}

This was an open label, randomized, crossover study with a 1-week washout period between two phases. The previous study had demonstrated that $2400 \mathrm{mg}$ of CRYR is a relevant comparison dose to $20 \mathrm{mg}$ of lovastatin for lowering blood cholesterol. ${ }^{7}$

Kantola et al. ${ }^{8}$ reported that grapefruit increased the serum levels of lovastatin $\left(\mathrm{C}_{\max }\right)$ approximately 12 -fold and the area under the concentration-time curve (AUC) 15-fold by inhibiting CYP3A4-mediated first-pass metabolism in the small intestine. The present study uses the preceding method to increase the detectable levels of monacolins.

The subjects were given $200 \mathrm{~mL}$ of double-strength grapefruit juice (Minute Maid frozen concentrated grapefruit juice, 12 fluid ounces $(355 \mathrm{~mL})$, Coca-Cola Foods, Houston, TX) three times per day (at $7 \mathrm{AM}$, noon, and 8 PM) for 2 days. On day 3, the subjects reported to the GCRC at 7:30 AM after fasting from 11 PM the previous day. A caffeine-free standardized breakfast was served at 7:45 AM and either $20 \mathrm{mg}$ of lovastatin or $2400 \mathrm{mg}$ of Chinese red yeast rice was given with $200 \mathrm{~mL}$ of double-strength grapefruit juice at 8 AM. Standardized lunch and dinner were served at noon and $5 \mathrm{pm}$. The subjects returned to the GCRC the next morning to have their blood last drawn at $8 \mathrm{AM}$.

\section{Sample collection}

On the day of administration of lovastatin or CRYR, a forearm vein of each subject was cannulated with a plastic cannula and kept patent with a heparin flush. Blood samples were obtained at $0,0.5,1,1.5,2,3,4,6,8$, and 24 hours after taking lovastatin or taking CRYR. Whole blood was centrifuged immediately and plasma transferred to plastic tubes and frozen at $-80^{\circ} \mathrm{C}$ until assay.

\section{Methodology for determination of monacolin \\ $K$ (lovastatin) and lovastatin hydroxy-acid in human plasma}

Lovastatin 20-mg capsules were purchased from Merck \& Co. Inc. (Whitehouse, NJ) CRYR dietary supplement 600mg capsules were provided by Beijing WBL Peking University Biotech Co., Ltd, China.

HPLC-MS analyses were carried out on an LCQ Classic Finnigan LC-MS/MS system (ThermoFinnigan, San Jose, CA), equipped with a HP 1100 series HPLC system consisting of an autosampler and injector, quaternary pump, column

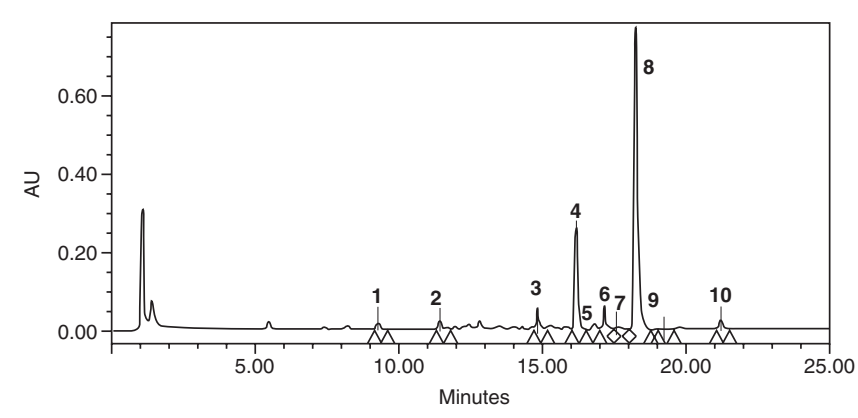

FIG. 1. High performance liquid chromatography trace of monacolins. 1, Monacolin Kanalogue; 2, Monacolin K dehydro analogue; 3, Hydroxy-acid form of Monacolin L; 4, Hydroxy-acid form of Monacolin K; 5, Dihydromonacolin K; 6, Monacolin L; 7, Hydroxy-acid form of dehydromonacolin K; 8, Monacolin K; 9 , Methyl ester of hydroxy-acid form of monacolin K; 10, Dehydromonacolin K. AU, absorbance. 
A

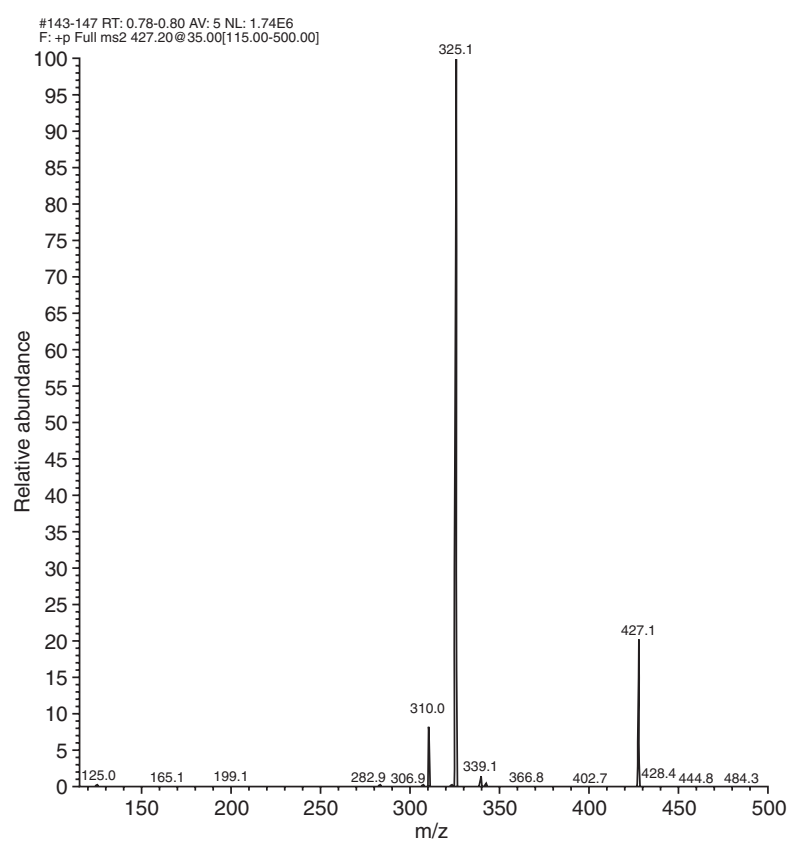

C

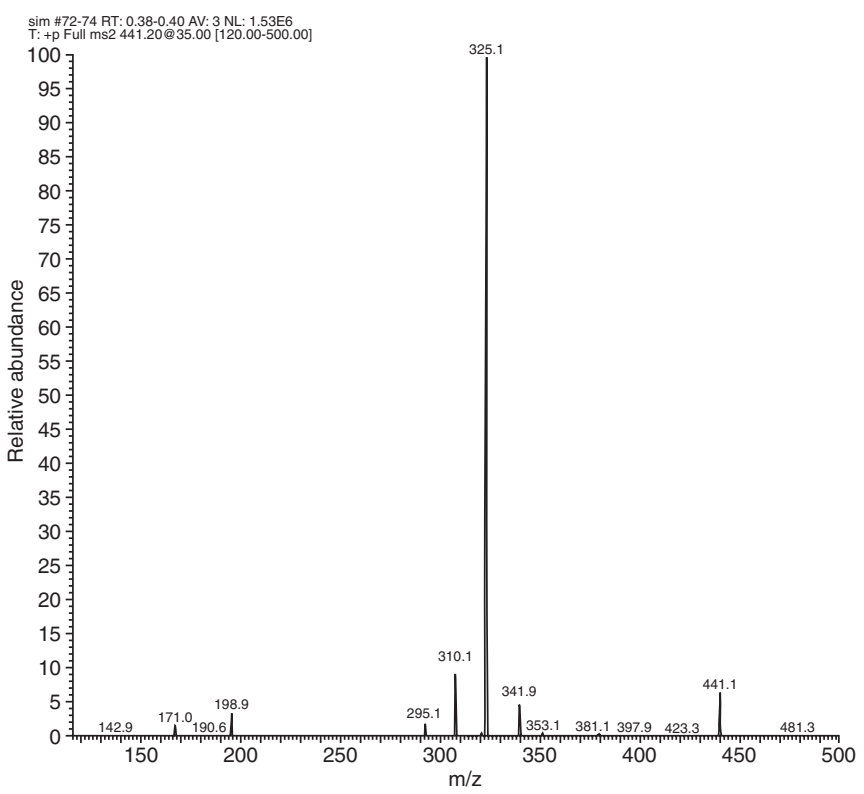

FIG. 2. A. Liquid chromatography-mass spectrometry (LCMS) trace of lovastatin (monacolin $\mathrm{K}$ ) standard. The molecular ion is at $\mathrm{m} / \mathrm{z} 427=[\mathrm{M}+\mathrm{Na}]^{+}$as reported. ${ }^{9}$ B. LCMS trace of lovastatin (monacolin $\mathrm{K}$ ) hydroxy-acid standard. The molecular ion at $\mathrm{m} / \mathrm{z} 421=[\mathrm{M}-\mathrm{H}]^{-}$as reported. ${ }^{9}$ C. LCMS trace of simvastatin standard. The molecular ion is at $\mathrm{m} / \mathrm{z} 441=[\mathrm{M}+\mathrm{Na}]^{+}$as reported. ${ }^{9}$

heater, and diode array detector (DAD). Data handling was carried out using Xcalibur 1.2 software (ThermoFinnigan). Conditions for detection were as follows: Column, Symmetry C-18, $100 \mathrm{~mm} \times 2.1$ i.d., $3.5 \mu \mathrm{m}$, (Waters Corp., Milford,

B

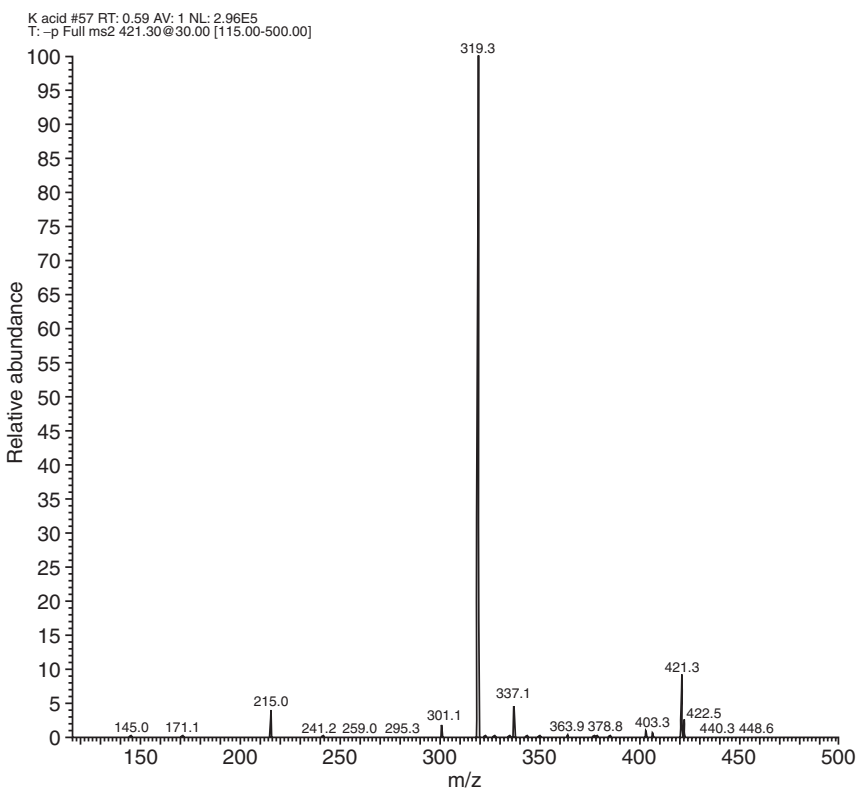

MA); Solvent A) $0.5 \%$ acetic acid/acetonitrile, B) $0.5 \%$ acetic acid/water; binary linear gradient system: 0-15 min: 50\% A in $\mathrm{B}$ to $90 \% \mathrm{~A}$ in $\mathrm{B} ; 15-18 \mathrm{~min}, 90 \% \mathrm{~A}$ in $\mathrm{B}$; flow rate 0.2 $\mathrm{mL} /$ minute; injection volume $20 \mu \mathrm{L}$; column temperature $25^{\circ} \mathrm{C}$. Mass spectrometer (MS) parameters: The MS (electrospray ionization; ESI) was operated in the negative mode for the first 11 minutes and then in the positive mode for the rest of the analytical run; scan range: 115-500 amu; scan rate: $1 \mathrm{scan} / \mathrm{sec}$; cone voltage: $17 \mathrm{eV}$. Peak identities for lovastatin, lovastatin hydroxy-acid, and simvastatin were obtained by comparison of their LC-MS/MS ions with their standards.

Each C8 SPE cartridge was preconditioned with methanol $(2 \times 1 \mathrm{~mL})$ and water $(2 \times 1 \mathrm{~mL})$. Each plasma sample $(400 \mu \mathrm{L})$ was loaded onto the cartridge and allowed to freeflow by gravity. Each cartridge was then eluted with consecutive aliquots of $1 \mathrm{~mL}$ water, $1 \mathrm{~mL} \mathrm{5 \%} \mathrm{formic} \mathrm{acid,} \mathrm{and}$ then $1 \mathrm{~mL}$ of water. The cartridge was allowed to drip dry, left to stand for 1 minute, then eluted with $1 \mathrm{~mL}$ methanol: water $(7: 3 \mathrm{v} / \mathrm{v})$ solution, and finally with $1 \mathrm{~mL}$ of acetonitrile. The combined acetonitrile eluates were evaporated to dryness in vacuo at low temperature, reconstituted in the HPLC mobile phase $(100 \mu \mathrm{L})$, vortexed for 1 minute, and injected onto the LC column for LC-MS analyses.

Plasma calibration standards of lovastatin and its hydroxy-acid were prepared by spiking control human plasma with known concentrations of working solutions of the standards. Samples were processed according to the extraction procedure and injected on to the HPLC-MS. Concentrations were determined from the peak area by using the equation for linear regression obtained from the calibration curve. The 
calibration curve was linear $\left(\mathrm{R}^{2}=0.9954\right.$ for lovastatin and 0.9927 for lovastatin hydroxy-acid, respectively) over the concentration range from 0.1 to $100 \mathrm{ng} / \mathrm{mL}$. The lower level of quantitation (LOQ) established from the calibration curve by LCMS was $0.1 \mathrm{ng} / \mathrm{mL}$ based on $400 \mu \mathrm{L}$ of plasma. Simvastatin was used as an internal standard as previously reported. ${ }^{9}$

\section{Statistical analysis}

The pharmacokinetic parameters, peak plasma concentration $\left(\mathrm{C}_{\max }\right)$, time to peak plasma concentration $\left(\mathrm{T}_{\max }\right)$, and time for appearance of the drug in plasma were obtained by observation. The AUC from 0 to 24 hours after dosing was calculated by the linear trapezoidal rule. Elimination half-life $\left(t_{1 / 2}\right)$ was estimated by $0.693 / \lambda$, where $\lambda$ is the absolute value of the slope of a least-square linear regression of plasma drug concentration (in natural logarithm scale) over time at the terminal phase.

The pharmacokinetic parameters of lovastatin and lovastatin hydroxy-acid were tabulated using mean \pm SEM for taking lovastatin and CRYR, respectively. This was a 2-by2 crossover study with 7-day washout period. No carryover effect was identified, and no significant period and sequence effects were found; therefore, signed rank test was used to compare the pharmacokinetic parameters for Lovastatin versus CRYR.

All tests used were two sided with a significance level of 0.05. Statistical software SAS was used to carry out the analysis.

\section{RESULTS}

\section{Characterization of the constituents of CRYR}

This botanical dietary supplement consists mainly of rice, and by-products of fermentation. The main groups of constituents are shown in Table 1. Clearly the most abundant ingredient is starch, constituting over $73 \%$ of the bulk. The protein content is $6 \%$. The other ingredients are found in much less quantity. Trace elements were analyzed by atomic absorption spectroscopy. Magnesium is the most abundant metal with $1094 \mu \mathrm{g} / \mathrm{g}$ of rice.

The typical HPLC trace for the monacolin mixture as found in CRYR is shown in Figure 1 and the Liquid Chromatography-Mass Spectrometry (LC-MS) traces of monacolin $\mathrm{K}$, monacolin $\mathrm{K}$ hydroxyl-acid, and simvastatin standards are shown in Figures $2 \mathrm{~A}-\mathrm{C}$, respectively. Figure 3 shows the LC-MS trace of a plasma sample obtained from a human subject with simvastatin added as internal standard where monacolin $\mathrm{K}$ and monacolin $\mathrm{K}$ hydroxy-acid were detected. There is $1.23 \mathrm{mg}$ of monacolin $\mathrm{K}$ in every capsule by assay of manufacture and $1.15 \mathrm{mg}$ by HPLC analyses under the same conditions.

\section{Pharmacokinetics}

The mean values and pharmacokinetics for lovastatin and CRYR are summarized in Table 2 and the mean plasma concentration versus time profiles for monacolin $\mathrm{K}$ and monacolin K hydroxy-acid are shown in Figures 4A,B, respectively. Monacolin K was detected in plasma 30 minutes after ingestion of either lovastatin or CRYR. The peak concentration reached at approximately 3 hours. The $\mathrm{C}_{\max }$ and $\mathrm{AUC}$ of lovastatin are $22.42 \mathrm{ng} / \mathrm{mL}$, and 80.47 higher than CRYR with $p$ value of 0.001 and 0.002 , respectively. The dose-normalized $\mathrm{C}_{\max }$ and AUC of lovastatin are $0.89+0.22 \mathrm{ng} / \mathrm{mL}$, and 3.41+0.99 higher than CRYR with $p$ value of 0.001 and 0.002 , respectively.

Monacolin K hydroxy-acid was detected 30 minutes after taking lovastatin or CRYR but peaked at 4 hours, 1 hour later than when monacolin $\mathrm{K}$ peaked. The $\mathrm{T}_{\max }$ for lovastatin and CRYR hydroxy-acids were similar $(p=1.00$, signed rank test). The $\mathrm{C}_{\max }$ for loavstatin hydroxy-acid is $36.63 \mathrm{ng} / \mathrm{mL}$ higher than the $\mathrm{C}_{\max }$ of CRYR hydroxy-acid ( $p=0.001$, signed rank test). The AUC of lovastatin hydroxy-acid is 258.5 larger than that of CRYR ( $p=0.001)$. After normalization for dose, the AUC of lovastatin is still 7.21 larger than that of CRYR $(p=0.001)$.

The individual sample for minor monacolins were not detectable by LC-MS/MS. However, the pooled plasma samples collected from three subjects showed the presence of minor monacolins reported to be present in CRYR. ${ }^{10}$ Sam-

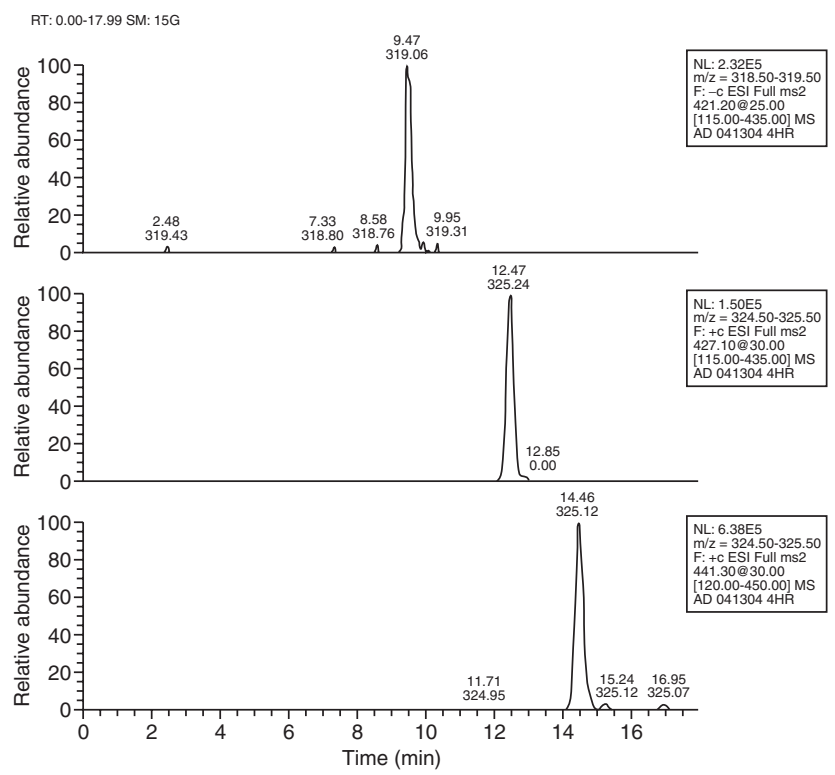

FIG. 3. LCMS trace of human plasma sample showing monacolin K hydroxy-acid $\left(t_{r}=9.47\right.$ min, base peak $\mathrm{m} / \mathrm{z} 319.06$ from molecular ion at $\mathrm{m} / \mathrm{z} 421)$; Monacolin $\mathrm{K}\left(\mathrm{t}_{\mathrm{r}}=12.47 \mathrm{~min}\right.$, base peak $\mathrm{m} / \mathrm{z} 325.24$ from molecular ion at $\mathrm{m} / \mathrm{z} 427)$; Simvastatin $\left(\mathrm{t}_{\mathrm{r}}=14.46\right.$ min, base peak at $\mathrm{m} / \mathrm{z} 325.12$ from molecular ion at $\mathrm{m} / \mathrm{z} 441.3$ ) according to a previous report. ${ }^{9}$ 
TABLE 2. $\mathrm{C}_{\mathrm{MAX}}, \mathrm{T}_{\mathrm{MAX}}$, AND AUC $\mathrm{A}-24 \mathrm{H}(\mathrm{MEAN} \pm \mathrm{SEM})$

\begin{tabular}{|c|c|c|c|c|}
\hline & \multicolumn{2}{|c|}{ Lovastatin } & \multicolumn{2}{|c|}{ Lovastatin hydroxy-acid } \\
\hline & Lovastatin & Chinese red yeast rice & Lovastatin & Chinese red yeast rice \\
\hline $\mathrm{C}_{\max }$ & $23.67 \pm 4.56$ & $1.25 \pm 0.26$ & $40.94 \pm 2.51$ & $4.31 \pm 0.79$ \\
\hline $\mathrm{T}_{\max }$ & $2.77 \pm 0.28$ & $3.05 \pm 0.24$ & $3.82 \pm 0.12$ & $3.82 \pm 0.30$ \\
\hline $\mathrm{AUC}_{0-24 \mathrm{~h}}$ & $83.64 \pm 21.35$ & $3.17 \pm 0.81$ & $287.97 \pm 26.78$ & $29.47 \pm 6.08$ \\
\hline $\mathrm{T}_{\text {lag }}$ & $0.75 \pm 0.15$ & $1.25 \pm 0.28$ & $0.80 \pm 0.14$ & $1.02 \pm 0.12$ \\
\hline$t_{1 / 2}$ & $1.22 \pm 0.04$ & $2.15 \pm 0.16$ & $2.60 \pm 0.40$ & $1.45 \pm 0.14$ \\
\hline
\end{tabular}

AUC, area under the curve.

ples from all subjects were analyzed after pooled with two subjects. All the analysis showed the same pattern of minor monacolins. The data from one analysis are shown in Figures 5 and 6 . Because of the unavailability of standards for these minor monacolins, Selected Ion Monitoring (SIM) was conducted in negative and positive ESI modes of CRYR, and then followed by MS-MS analyses of ions corresponding to each monacolin peak (Figs. 5 and 6). Peak identities were obtained by matching their molecular ions $(\mathrm{M}-\mathrm{H})^{-}$ or $(\mathrm{M}+\mathrm{Na})^{+}$obtained by ES-MS/MS ions with expected values. ${ }^{10}$ Figure $5 \mathrm{~A}$ shows the LCMS trace of the CRYR extract in negative mode with corresponding MS/MS ions for monacolin $\mathrm{K}$ hydroxy-acid ( $\mathrm{t}_{\mathrm{R}} 11.38 \mathrm{~min} ; \mathrm{M}-\mathrm{H} \mathrm{m} / \mathrm{z}$ 421), dehydromonacolin K hydroxy-acid ( $t_{R} 8.36$ min; $M-$ $\mathrm{H} \mathrm{m} / \mathrm{z}$ 403), monacolin L hydroxy-acid ( $\mathrm{t}_{\mathrm{R}} 9.49 \mathrm{~min} ; \mathrm{M}-$ $\mathrm{H} \mathrm{m} / \mathrm{z} 321)$ and dihydromonacolin $\mathrm{K}$ hydroxy-acid $\left(\mathrm{t}_{\mathrm{R}} 14.10\right.$ $\mathrm{min} ; \mathrm{M}-\mathrm{H} \mathrm{m} / \mathrm{z} 423$ ). Figure $5 \mathrm{~B}$ shows the LCMS trace of the pooled human plasma sample with ions corresponding to monacolin $\mathrm{L}$ hydroxy-acid ( $\mathrm{t}_{\mathrm{R}} 9.49 \mathrm{~min} ; \mathrm{M}-\mathrm{H} \mathrm{m} / \mathrm{z} 423$ ) and dihydromonacolin $\mathrm{K}$ hydroxy-acid ( $\mathrm{t}_{\mathrm{R}} 14.09 \mathrm{~min} ; \mathrm{M}-$ $\mathrm{H} \mathrm{m} / \mathrm{z} 423$ ). Similarly, Figure 6A shows the LCMS trace of the CRYR extract in positive mode with corresponding MS/MS ions for monacolin $\mathrm{K}\left(\mathrm{t}_{\mathrm{R}} 14.47 \mathrm{~min} ; \mathrm{M}+\mathrm{Na}, \mathrm{m} / \mathrm{z}\right.$ $427)^{+}$, dihydromonacolin $\mathrm{K}\left(\mathrm{t}_{\mathrm{R}} 17.26 \mathrm{~min} ; \mathrm{M}+\mathrm{Na}, \mathrm{m} / \mathrm{z}\right.$

A

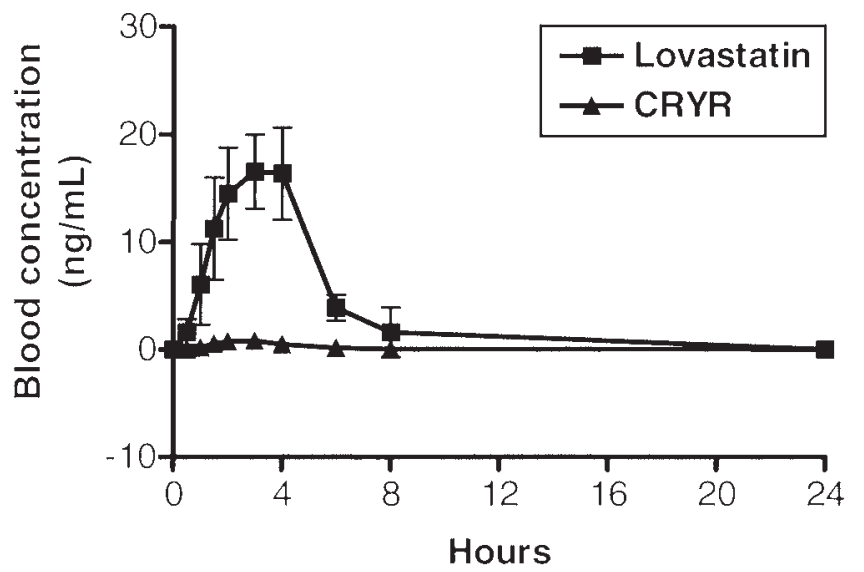

429) ${ }^{+}$, monacolin $\mathrm{L}\left(\mathrm{t}_{\mathrm{R}} 13.28 \mathrm{~min} ; \mathrm{M}+\mathrm{Na}, \mathrm{m} / \mathrm{z} 327\right)^{+}$, and dehydromonacolin $K\left(t_{R} 18.90 \mathrm{~min} ; \mathrm{M}+\mathrm{Na}, \mathrm{m} / \mathrm{z} 409\right)$. Figure 6B shows the LCMS trace of pooled plasma sample with ions corresponding to dehydromonacolin $\mathrm{K}\left(\mathrm{t}_{\mathrm{R}} 18.82 \mathrm{~min}\right.$; $\mathrm{M}+\mathrm{Na}, \mathrm{m} / \mathrm{z}$ 409).

\section{DISCUSSION}

In 1979, Endo ${ }^{11}$ reported that a strain of Monascus yeast naturally produces a substance that inhibits cholesterol synthesis, which he named monacolin $\mathrm{K}$, as well as a family of eight monacolin-related substances with the ability to inhibit 3-hydroxy-3-methylglutaryl coenzyme A (HMG-CoA) reductase. In addition to the inhibitors of HMG-CoA reductase, red yeast rice has been found to contain sterols ( $\beta$-sitosterol, campesterol, and stigmasterol), tannins, polyketide pigments, sapogenin, isoflavones and isoflavone glycosides, and monounsaturated fatty acids..$^{11,12}$

CRYR has been shown to lower cholesterol in animals fed diets designed to induce hypercholesterolemia. ${ }^{13,14}$ In a double-blind placebo-controlled and diet-controlled study, CRYR was demonstrated to lower serum cholesterol by $23 \%$ in 40 hypercholesterolemic patients compared to 40 patients

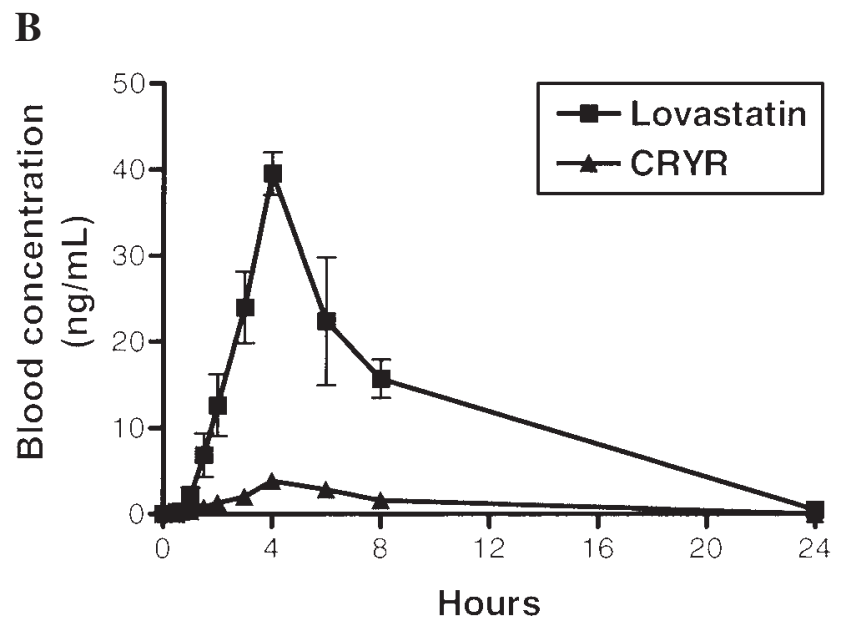

FIG. 4. A. Plasma concentration versus time profile for monacolin K. B. Plasma concentration versus time profile for monacolin K hydroxy-acid. 
A
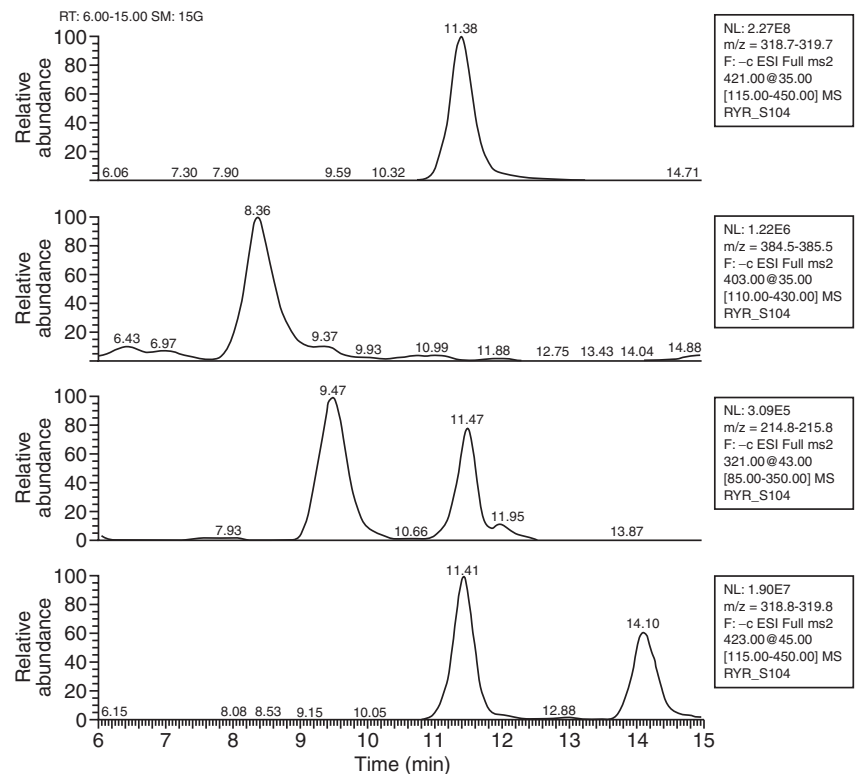

B

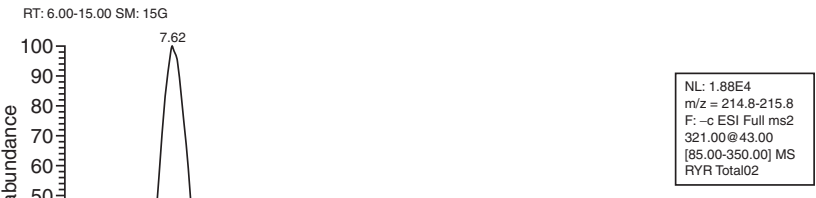

FIG. 5. A. Selected ion monitoring (SIM) spectra of the Chinese red yeast rice (CRYR) extract in negative mode with corresponding MS/MS ions for monacolin K hydroxy-acid ( $\mathrm{t}_{\mathrm{R}} 11.38 \mathrm{~min} ; \mathrm{M}-\mathrm{H} \mathrm{m} / \mathrm{z} 421$ ), dehydromonacolin $\mathrm{K}$ hydroxy-acid ( $\mathrm{t}_{\mathrm{R}} 8.36 \mathrm{~min} ; \mathrm{M}-$ $\mathrm{H} \mathrm{m} / \mathrm{z} 403)$, monacolin $\mathrm{L}$ hydroxy-acid ( $\left.\mathrm{t}_{\mathrm{R}} 9.49 \mathrm{~min} ; \mathrm{M}-\mathrm{H} \mathrm{m} / \mathrm{z} 321\right)$, and dihydromonacolin $\mathrm{K}$ hydroxy-acid $\left(\mathrm{t}_{\mathrm{R}} 14.10 \mathrm{~min} ; \mathrm{M}-\mathrm{H} \mathrm{m} / \mathrm{z}\right.$ 423). B. SIM spectra of the pooled human plasma sample with corresponding MS/MS iosn for monacolin L hydroxy-acid ( $\mathrm{t}_{\mathrm{R}} 9.49 \mathrm{~min}$; $\mathrm{M}-\mathrm{H} \mathrm{m} / \mathrm{z} 321$ ) and dihydromonacolin $\mathrm{K}$ hydroxy-acid ( $\left.\mathrm{t}_{\mathrm{R}} 14.09 \mathrm{~min} ; \mathrm{M}-\mathrm{H} \mathrm{m} / \mathrm{z} 423\right)$.

A
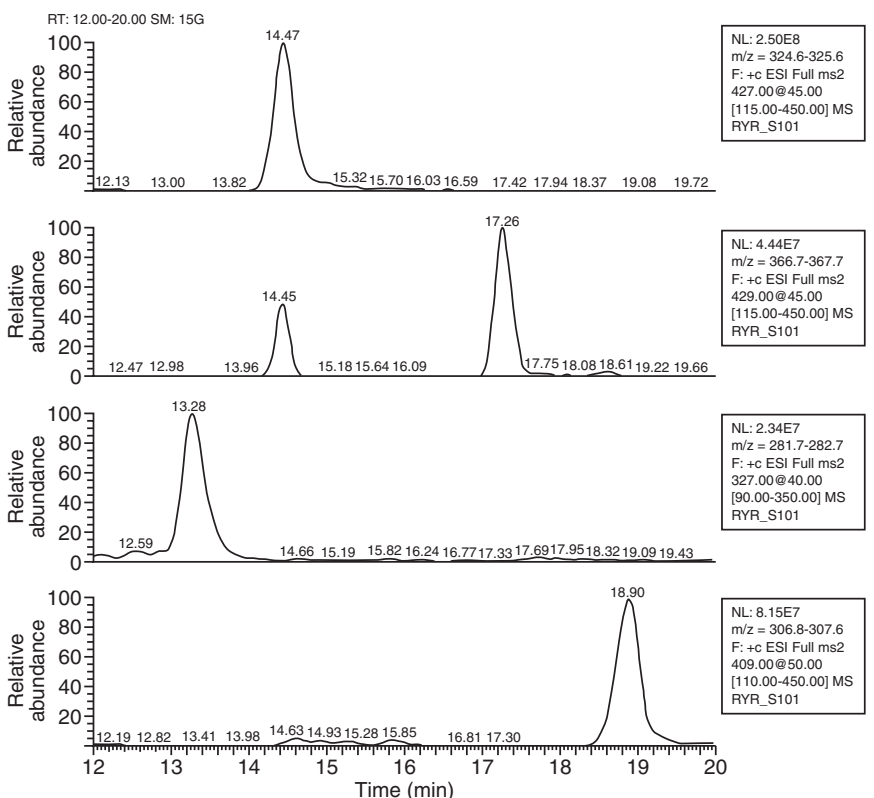

B

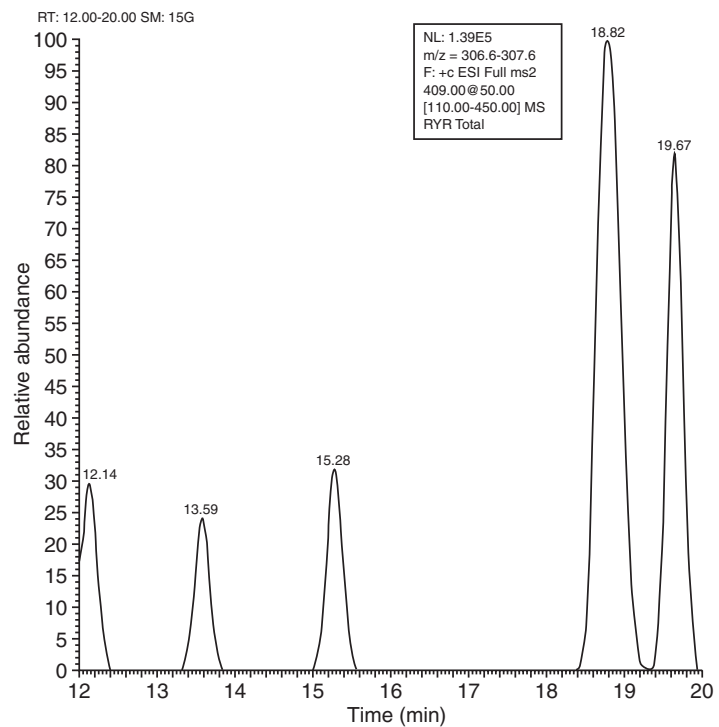

FIG. 6. A. Selected ion monitoring (SIM) spectra of the Chinese red yeast rice (CRYR) extract in positive mode with corresponding MS/MS ions for monacolin $\mathrm{K}\left(\mathrm{t}_{\mathrm{R}} 14.47 \mathrm{~min} ; \mathrm{M}+\mathrm{Na}^{+}, \mathrm{m} / \mathrm{z} 427\right)$, dihydromonacolin $\mathrm{K}\left(\mathrm{t}_{\mathrm{R}} 17.26 \mathrm{~min} ; \mathrm{M}+\mathrm{Na}^{+}, \mathrm{m} / \mathrm{z} 429\right)$, monacolin $\mathrm{L}\left(\mathrm{t}_{\mathrm{R}} 13.28 \mathrm{~min} ; \mathrm{M}+\mathrm{Na}^{+}, \mathrm{m} / \mathrm{z}\right.$ 327), and dehydromonacolin $\mathrm{K}\left(\mathrm{t}_{\mathrm{R}} 18.90 \mathrm{~min} ; \mathrm{M}+\mathrm{Na}^{+}, \mathrm{m} / \mathrm{z} 409\right)$. B. SIM spectra of pooled human plasma sample with ion corresponding to dehydromonacolin $\mathrm{K}\left(\mathrm{t}_{\mathrm{R}} 18.82 \mathrm{~min} ; \mathrm{M}+\mathrm{Na}^{+}, \mathrm{m} / \mathrm{z} 409\right)$. 
given placebo. ${ }^{7}$ The monacolins in CRYR and drug statins are competitive inhibitors of HMG CoA reductase, the regulatory enzyme of cholesterol synthesis. ${ }^{15}$

The current study showed that the quantity of monacolin $\mathrm{K}$ contained in CRYR is much lower and is inadequate to explain the magnitude of cholesterol lowering observed in the previous study. The $2400 \mathrm{mg}$ CRYR used in this study contains only $4.6 \mathrm{mg}, 23 \%$ of monacolin $\mathrm{K}$ of $20 \mathrm{mg}$ lovastatin. The findings of this study demonstrated that the plasma concentrations of monacolin $\mathrm{K}$ and its hydroxy-acid form are much higher after ingestion of lovastatin than CRYR. The mixture of monacolins and other substances present in the red yeast rice may have some inhibitory effect on cholesterol biosynthesis. Pooled plasma collected from three subjects showed the presence of additional minor monacolins that are known to be present in red yeast rice. ${ }^{10}$

Various synthetic statins have different degrees of biologic activity, and it is possible that the family of monacolins in CRYR may have a different profile of cellular or molecular actions. In the current study the monacolin $\mathrm{K}$ to monacolin K hydroxy-acid ratio was 1.72 for lovastatin and 3.48 for CRYR, which further suggests possible different metabolism. At 72 hours after administration, approximately $83 \%$ of lovastatin was excreted in stool and $10 \%$ in urine. ${ }^{16}$ Similar studies of the bioavailability and bioactivity of CRYR monacolins were not performed previously but would increase the understanding of the metabolism of this botanical dietary supplement.

Whereas the proprietary product used in this study was demonstrated to lower cholesterol levels significantly in clinical trials, other products being sold as CRYR dietary supplements have not undergone similar evaluation. Nine proprietary CRYR supplements were analyzed and it was found that the total monacolin content can vary from $0 \%$ to $0.58 \% \mathrm{w} / \mathrm{w}$, only $1 / 9$ preparations had the full complement of 10 monacolin compounds. ${ }^{17}$

Most of the pharmacokinetic data reported for statins in the literature have been generated using the HMG-CoA reductase assay to determine total and active inhibitors of HMG-CoA reductase. ${ }^{18}$ Although this enzymatic method can determine the entire latent and active drug and metabolites of lovastatin, it is not chemically specific. In contrast, the LC-MS/MS method used for determining plasma drug concentrations in this study is more sensitive and specific. ${ }^{9}, 19$ By using LC-MS/MS methodology, lovastatin was detectable a half hour after the 20 -mg dose was administered.

The benefits of statin drugs on the primary prevention of heart disease ${ }^{20,21}$ and in the secondary prevention of recurrent heart disease ${ }^{22,23}$ have been shown in several large, prospective clinical trials. These studies have increased interest in the prophylactic use of statins for heart disease prevention for individuals with hypercholesterolemia. The National Cholesterol Education Program (NCEP) guidelines were updated recently about pharmacologic intervention. NCEP is now advocating more aggressive therapy for patients with high and moderate risks. ${ }^{24}$ Although it is acknowledged that side-effects with statins are rare, there are data indicating that some statins may cause liver function abnormalities and, under certain circumstances, rhabdomyolysis in a doserelated fashion. ${ }^{25}$ Combined use of different statins in lower doses may decrease the incidence of side-effects.

\section{CONCLUSIONS}

In summary this study demonstrated significantly lower serum monacolin $\mathrm{K}$ level for CRYR compared to equivalent cholesterol-lowering dose of lovastatin. CRYR may serve as a safe and effective natural alternative for people with modest elevation of cholesterol. The effect of red yeast rice on the cholesterol concentration is not caused by monacolin $\mathrm{K}$ alone but the combination of monacolin $\mathrm{K}$ and other monacolins, substances in the red yeast rice supplement.

\section{ACKNOWLEDGMENTS}

Funding was supplied by the PHS/Institute of National Health IP50 AT 000151-01.

\section{REFERENCES}

1. Simons LA, Levis G, Simons J. Apparent discontinuation rates in patients prescribed lipid-lowering drugs. Med J Aust 1996; 164:208-211.

2. Eisenberg DM, Davis RB, Ettner SL, et al. Trends in alternative medicine use in the United States, 1990-1997: Results of a follow-up national survey. JAMA 1998;280:1569-1575.

3. Wootton JC, Sparber A. Surveys of complementary and alternative medicine: Part I. General trends and demographic groups. J Altern Complement Med 2001;7:195-208.

4. Havel RJ. Dietary supplement or drug? The case of cholestin. Am J Clin Nutr 1999;69:175-176.

5. Stuart MD. Chinese materia medica: Vegetable kingdom. Taipai, Republic of China: Southern Materials Center, 1979.

6. Martinkova L, Patakova-Juzlova P, Krent V, et al. Biological activities of oligoketide pigments of Monascus purpureus. Food Addit Contam 1999;16:15-24.

7. Heber D, Yip I, Ashley JM, Elashoff DA, Elashoff RM, Go VL. Cholesterol-lowering effects of a proprietary Chinese red-yeast-rice dietary supplement. Am J Clin Nutr 1999;69: 231-236.

8. Kantola T, Kivisto KT, Neuvonen PJ. Grapefruit juice greatly increases serum concentrations of lovastatin and lovastatin acid. Clin Pharmacol Ther 1998;63:397-402.

9. Wu Y, Zhao J, Henion J, Korfmacher WA, Lapiguera AP, Lin CC. Microsample determination of lovastatin and its hydroxy acid metabolite in mouse and rat plasma by liquid chro- 
matography/ionspray tandem mass spectrometry. J Mass Spectrom 1997;32:379-387.

10. Ma J, Li Y, Ye Q, et al. Constituents of red yeast rice, a traditional Chinese food and medicine. J Agric Food Chem 2000; 48:5220-5225.

11. Endo A. Monacolin K: A new hypocholesterolemic agent produced by a Monascus species. J Antibiot (Tokyo) 1979;32: 852-854.

12. Wu LC, Chen YC, Ho JA, Yang CS. Inhibitory effect of red koji extracts on mushroom tyrosinase. J Agric Food Chem 2003;51:4240-4246.

13. Wei W, Li C, Wang Y, Su H, Zhu J, Kritchevsky D. Hypolipidemic and anti-atherogenic effects of long-term Cholestin (Monascus purpureus-fermented rice, red yeast rice) in cholesterol fed rabbits. J Nutr Biochem 2003;14:314-318.

14. Li C, Zhu Y, Wang Y, Zhu J-S, Chang J, Kritchevsky D. Monascus purpureus-fermented rice (red yeast rice): A natural food product that lowers blood cholesterol in animal models of hypercholesterolemia. Nutrition Res 1998;18:71-81.

15. Edwards PA, Popjak G, Fogelman AM, Edmond J. Control of 3-hydroxy-3-methylglutaryl coenzyme A reductase by endogenously synthesized sterols in vitro and in vivo. J Biol Chem 1977;252:1057-1063.

16. Duggan DE, Chen IW, Bayne WF, et al. The physiological disposition of lovastatin. Drug Metab Dispos 1989;17:166-173.

17. Heber D, Lembertas A, Lu QY, Bowerman S, Go VL. An analysis of nine proprietary Chinese red yeast rice dietary supplements: Implications of variability in chemical profile and contents. J Altern Complement Med 2001;7:133-139.

18. Erturk S, Onal A, Muge CS. Analytical methods for the quantitative determination of 3-hydroxy-3-methylglutaryl coenzyme A reductase inhibitors in biological samples. J Chromatogr B Analyt Technol Biomed Life Sci 2003;793:193-205.

19. Lamson M, Phillips G, Shen J, Lukacsko P, Friedhoff L, Niecestro RM. Pharmacokinetics of lovastatin extended-release dosage form (Lovastatin XL) in healthy volunteers. Biopharm Drug Dispos 2002;23:143-149.

20. Downs JR, Clearfield M, Weis S, et al. Primary prevention of acute coronary events with lovastatin in men and women with average cholesterol levels: Results of AFCAPS/TexCAPS. Air Force/Texas Coronary Atherosclerosis Prevention Study. JAMA 1998;279:1615-1622.

21. Shepherd J, Cobbe SM, Ford I, et al. Prevention of coronary heart disease with pravastatin in men with hypercholesterolemia. West of Scotland Coronary Prevention Study Group. N Engl J Med 1995;333:1301-1307.

22. Sacks FM, Pfeffer MA, Moye LA, et al. The effect of pravastatin on coronary events after myocardial infarction in patients with average cholesterol levels. Cholesterol and Recurrent Events Trial investigators. N Engl J Med 1996;335:1001-1009.

23. Randomised trial of cholesterol lowering in 4444 patients with coronary heart disease: The Scandinavian Simvastatin Survival Study (4S). Lancet 1994;344:1383-1389.

24. Grundy SM, Cleeman JI, Merz CN, et al. Implications of recent clinical trials for the National Cholesterol Education Program Adult Treatment Panel III Guidelines. J Am Coll Cardiol 2004;44:720-732.

25. Bellosta S, Paoletti R, Corsini A. Safety of statins: Focus on clinical pharmacokinetics and drug interactions. Circulation 2004;109:III50-III57.

Address reprint requests to: Zhaoping Li, Ph.D., M.D.

Center for Human Nutrition David Geffon School of Medicine University of California, Los Angeles 900 Veteran Avenue, Room 12-217 Los Angeles, CA 90095-1742

E-mail: zli@mednet.ucla.edu 
Copyright of Journal of Alternative \& Complementary Medicine is the property of Mary Ann Liebert. Inc. and its content may not be copied or emailed to multiple sites or posted to a listserv without the copyright holder's express written permission. However, users may print, download, or email articles for individual use. 